\title{
Transnational Alternative Policy Groups in Global Civil Society: Enablers of Post- Capitalist Alternatives or Carriers of NGOization?
}

[Final version - Published in Critical Sociology, 2015-06-03. doi:10.1177/0896920515589004]

\author{
William K. Carroll \\ University of Victoria, Canada
}

\section{Jean Philippe Sapinski}

University of Victoria, Canada

\begin{abstract}
Since the 1970s, transnational alternative policy groups (TAPGs) have generated visions and strategies pointing to alternatives to capitalist globalization. However, TAPGs are also embedded in networks of intergovernmental organizations (IGOs) and foundations, and may thus be subject to NGOization. This paper examines two bodies of data relevant to this issue: (1) network data that highlight TAPGs' links to major sources of funds as well as key IGOs; (2) reflections of TAPG protagonists gleaned from in-depth interviews conducted at these groups. While our network analysis is consistent with the NGOization narrative, and while our participants offered many narratives of their own in line with it, they also provided more nuanced accounts that begin to specify the contingencies mediating between, on the one hand, resort to formal organization and to working with IGOs and foundations, and on the other hand, descent into hegemonic incorporation. In a neoliberal political-economic environment, the future of counter-hegemonic politics hinges partly on our identifying how 'preventative measures' can be brought to bear on processes of NGOization.
\end{abstract}

\section{Keywords}

global civil society, counter-hegemony, NGOization, transnational networks, social movements 


\section{Introduction}

In the past decade, intellectuals associated with the World Social Forum, most prominently Santos (2006), have suggested that a 'global left' is in the making, catalyzed both by popular resistance to transnational neoliberalism and by the collective learning processes associated with the Forum and related developments. An important infrastructure for such a formation can be found in the global activist networks that have been assembled as social movements have internationalized their strategies and practices (Keck and Sikkink, 1998) and, in some cases, embraced a politics of alterglobalization (Carroll, 2013; Hervé, 2014).

The making of this global left is not without its complexities and debates. Global social movements are embedded within broader political relations. One of the challenges faced by movements is that of establishing an 'infrastructure of dissent' (Sears 2014) to ensure long-term viability, which requires an certain degree of organization as well as recurring sources of funding. However, movements and groups choosing to go that route then find themselves treading a narrow path between enabling counter-hegemonic discourses and actions and the necessity to secure funding, which often comes from hegemonic organizations such as corporate philanthropic foundations and transnational state agencies (Harcourt, 2013; Lang, 2013). This paper will outline some of these tensions, widespread among the emerging global left, and delineate some of the strategies that movement actors employ to address them.

An infrastructure of dissent requires, among other things, the means for producing counterhegemonic knowledge that gains traction in political practice. Recent research on transnational alternative policy groups (TAPGs) has emphasized the role that Focus on the Global South, the Transnational Institute and other TAPGs play in producing alternative visions, strategies and policies in dialogue with movements, and in disseminating this knowledge across a wide range of counter-publics as well as general publics (Carroll, 2013, 2014). A study of the network of international nongovernmental organizations (INGOs) in which sixteen TAPGs are embedded showed that these groups 'communicate with and mediate between a diverse array of collective 
actors, North and South,' and serve as 'important elements in counter-hegemony, across a wide range of political domains' (Carroll and Sapinski, 2013: 235).

However, the authors also registered some doubts about this sanguine reading of the data. The structural analysis of the network did not examine the substantive content of the relations between organizations, nor did it explore relations between TAPGs and dominant institutions such as foundations and intergovernmental organizations (IGOs). Ties supporting an inference that TAPGs are active agents of counter-hegemony might also be read as indicators of a gatekeeping role that co-opts movements into dominant hegemonies and marginalizes their more radical elements. A formal tie between say a Northern and a Southern-based group may entail solidaristic mutual aid, but it could also be imbued with some form of asymmetrical dependence and constraint. According to an alternative reading of the findings, TAPGs (or some of them), despite their political ambitions, could be caught up in a process of NGOization. In this reading, with the retreat of neoliberal states from direct social programming and through processes of increasing professionalization and institutionalization, NGOs come to be seen by governments and IGOs as 'surrogates for civil society' and are subcontracted to advise on or deliver government programs (Alvarez, 1999: 181). This 'neoliberalization of civil society' (Goldman, 2005: 270-1) places NGOs into the role of gatekeepers for national and global governance, and 'as brakes on more radical and exceptional ideas emanating from the developing world' (Bob, 2005: 194). Within this account the intermediary role TAPGs play may have more to do with 'maintaining the hegemonic bloc, than with constructing a counter-hegemonic alternative' (Carroll and Sapinski, 2013: 236-7; cf. Choudry, 2010).

This paper follows through on two recommendations from the earlier analysis. It presents a network analysis that goes beyond the links between TAPGs and INGOs to the foundations that fund TAPGs and the IGOs with which TAPGs are often heavily engaged. And it goes beyond architectonic network analysis to explore, from in-depth interviews with protagonists in TAPGs, their own views on how their cognitive praxis is shaped by their ongoing needs for funding and by the pull of NGOization within global civil society. 


\section{IGOs, foundations and the process of NGOization}

Since James Petras presented the first major critique in a 1997 Monthly Review article, many authors have interrogated the role of NGOs in the process of neoliberal globalization, giving rise to an NGOization grand narrative. In this account, NGOs rose to prominence during the 1980s, following the roll back of the state in peripheral countries under World Bank and IMF imposed structural adjustment programs. NGOs came to play programmatic roles previously assumed by the state, assuming a new 'function' under the neoliberal regime (Ferguson, 2006; Goldman, 2005: 270-1; Shiviji, 2007).

Complementing the new function, NGOization has meant selective political inclusion: groups willing to cooperate and compromise with states and IGOs gain access and resources; radical critics are excluded (sometimes leading to their criminalization and repression). This process can strengthen the hegemony of political institutions by presenting an image of openness and pluralism while dividing 'civil society' into 'good' and 'bad', with the latter dismissed as rigid, closed and extremist (Scholl and Fryberg-Inan, 2013; Dupuis-Déri, 2013).

The term NGOization also captures the tendency of social movements to institutionalize and to adopt the form of professional NGOs, dependent on funding from governments, IGOs and private foundations (Choudry, 2010; Choudry and Kapoor, 2013; Dauvergne and LeBaron, 2014). Such moves may derive from strong financial pressures to engage in 'partnerships' with IGOs/the UN system (Smith, 2012: 18; see also Lang 2013). In the NGOization narrative, professionalization leads NGOs to assume state-like functions of service delivery or funding provision, placing them in the position of gatekeepers between hegemonic institutions and their constituencies (Choudry, 2010).

With professionalization comes an elite of NGO managers, who may have more in common with state, IGO and corporate bureaucrats and managers, than with the constituencies their organizations purport to represent, as they seek to build their careers and ensure a stable living situation (Choudry, 2010; Guilhot, 2007). NGOization also promotes adoption of corporate organizational models which seek legitimacy in the eyes of funders instead of from the 
movement base (Choudry and Kapoor, 2010: 6; Choudry, 2010; INCITE!, 2007). In the NGOization narrative, as social movements become NGOs they carve niches for themselves in a global division of labor that reinforces hegemony by restraining (rather than fostering) the critical ideas that emanate from the "base" or the developing world (Guilhot, 2007: 473; Bob, 2005: 194).

However, the field of global politics is complex. IGOs can be conceptualized as places of struggle where civil society organizations work to bring about policy change, as in the struggle that La Via Campesina and other groups have waged for influence within the UN's Food and Agricultural Organization (FAO), which highlights both the compromises required to maintain access and the constant scrutiny to which participating NGOs are held by social movement activists (McKeon, 2009; Brem-Wilson, 2015). Looking at longer term dynamics, Smith and Wiest (2012) observe that the 1990s wave of UN-sponsored international summits encouraged an intense engagement by civil society with IGOs, but that, with the establishment of the World Social Forum (WSF) in 2001 transnational activist groups increasingly organized their own meetings.

To understand the context of the action of NGOs and social movements in the global political field, it is crucial to take into account the sources of funding on which many of these groups depend. As explained above, IGO and state funding entails a series of constraints within which NGOs must work. Other major funders are large corporate-sponsored foundations such as the Ford Foundation or Georges Soros' Open Society Foundations. State and corporate elites, whose members tend to intermingle, share certain interests in fostering socio-political stability to enable continued capital accumulation, which are advanced by the work of foundations (Parmar, 2012: par. 10). Foundations allocate their money in a systematic way toward organizations and projects that ultimately advance their own goals of mitigating the worst effects of neoliberal capitalism, and preserving stability, so as to "channel all protest and dissent into activities that do not threaten the wealth and power of the large corporations, or their access to the resources and the markets of the world" (Feldman, 2007: 429; Research Unit for Political Economy, 2007). Foundations thereby sponsor an opposition that the globalizing corporate liberal elite can 
tolerate, forestalling the emergence of a truly oppositional movement (Feldman, 2007: 445). They concomitantly help build a global institutional architecture composed of certain "strategic minorities" that can provide a social base for a project of "soft" globalization, a neoliberalism "blunted at the edges" (Parmar 2012: par. 65), a "compromise" acceptable to mainstream Northern-based civil society. As foundations vie to capture and becalm contested fields, they play a major role in NGOization (see Guilhot, 2007; Research Unit for Political Economy, 2007).

The implications of this analysis for transnational alternative policy groups are important. To the extent that relations of financial dependence and processes of NGOization coopt and constrain TAPGs, their capacity to help organize and inform an emergent global left would be grievously compromised. Below, we examine two bodies of data relevant to this issue: (1) network data that fill out the earlier analysis in Carroll and Sapinski (2013) of how TAPGs are embedded in a global political field, highlighting their links to foundations and IGOs/state bodies; (2)

reflections of TAPG protagonists gleaned from interviews conducted at these groups in 2012 and 2013. The former gives us a mapping of how TAPGs are positioned in a political-economic field that includes not only INGOs but hegemonic institutions. The latter enables us to explore how organic intellectuals working within TAPGs construe the challenges posed by financial dependence and NGOization, and the kinds of defenses or responses their organizations have mounted.

\section{Network analysis}

To isolate a network relevant to our analytical interest, we began with the same 16 TAPGs that Carroll and Sapinski (2013) researched (see Table 1). Using a snowball sampling methodology, we identified all the international organizations directly linked to the 16 TAPGs, i.e., their immediate neighbors. ${ }^{1}$ We then identified the linkages between all immediate neighbors, enabling us to map the complete network of 16 TAPGs and their immediate neighbors. Our source was the 2012 edition of the Yearbook of International Organizations (YIO), published by the Union of International Associations (UIA 2012), whose classifications enable us to distinguish between foundations, IGOs and INGOs. ${ }^{2}$ The $Y I O$ lists a variety of different types of affiliations for each 
organization. For present purposes we included all types of affiliations, to capture all collaborations and other substantive linkages between organizations. ${ }^{3}$

\section{[TABLE 1 HERE]}

The entire network is comprised of 16 TAPGs, 41 IGOs/state bodies, 30 foundations and 233 INGOs, indicating that TAPGs link predominantly to INGOs, but that foundations and intergovernmental/state organizations also have a presence in the network. Moreover, in Table 2 we see that TAPGs are especially proximal to each other in the network (on average, a pair of TAPGs can reach each other at distance 2.092, i.e., through one intermediary), but also that mean distances among the four types of organizations do not range very widely. On average, TAPGs are particularly close to the many INGOs in the network, but the greatest mean distance (between INGOs and IGOs, 3.078) is not dramatically higher than that between INGOs and TAPGs (2.528). Clearly, the network is well integrated, including the 30 foundations and 41 IGOs/state bodies, which are themselves interconnected by a total of 48 ties, 29 of them linking IGOs to foundations - a pattern consistent with the idea that these organizations form a hegemonic structure of governance and funding.

\section{[TABLE 2 HERE]}

Table 3 details the size and composition of each TAPG's immediate neighborhood. TAPGs vary dramatically in the number of organizations they are affiliated with in some way, with Focus ${ }^{4}$ and CCS maintaining neighborhoods of 50 organizations while NIGD's neighborhood includes only five organizations. IGOs and state bodies make up close to $12 \%$ of TAPGs' neighborhood on average, and foundations about $6 \%$. A high proportion of foundations and IGOs in the immediate neighborhood indicates that a TAPG links more to these hegemonic organizations than to other INGOs. Again, there is dramatic variation among groups. Almost $50 \%$ of PRIA's links are to foundations and IGOs; TNI and DAWN also have a large proportion of ties to such organizations. Conversely, CACIM, TWF and IFG have few or no links to foundations and IGOs. TAPGs also vary greatly in the degree to which they collaborate with each other. Among 
TAPGs with relatively large neighborhoods, Focus, TNI, TWF and CCS maintain fairly extensive relations with other TAPGs.

\section{[TABLE 3 HERE]}

A key question relevant to the issue is NGOization is whether, at the center of the network, we find an intermingling of TAPGs, foundations and IGOs. To explore this issue, we restricted the analysis to these organizations, and found that 14 of the 16 TAPGs participate in a single connected network of 81 organizations, including $41 \mathrm{IGOs} /$ state bodies and 26 foundations. Disregarding pendants (organizations with only one tie to another network member), we isolated a block of 13 TAPGs, 17 IGOs and 20 foundations, each linked to at least two other block members. Within that central block, we identified a 3-core composed of nine TAPGs, 12 foundations and 13 IGOs (see Figure 1). ${ }^{5}$ The 3-core shown is the network's dense center. Only $42 \%$ of the 81 organizations belong to the 3 -core, but $60 \%$ of all the 149 lines in the entire network are concentrated among 3-core members. Another 35\% of all lines link 3-core members to non-members, leaving only $5 \%$ of lines connecting the 47 non-members with each other.

\section{[FIGURE 1 HERE]}

\section{[TABLE 4 HERE]}

The pattern of relationships in Figure 1 gives us a sense how the TAPGs, foundations and IGOs at the core of the network intermingle. Four TAPGs with strong left orientations - RosaLux, Focus, TNI and CCS - link with each other, and two of them also link with the UN IGOs $\mathrm{UNCTAD}^{6}$ and UNFCCC. RosaLux (which is funded by the German state and is itself a source of funds for many left organizations) also connects with TWN, which in turn links to two UN IGOs as well as the DHF. Another cluster of TAPGs (PRIA, ITeM and DAWN) have in common ties to the Ford Foundation and to UNDP. PRIA and DAWN also link with UNICEF, while ITeM and DAWN are both tied to the UN IGO ECOSOC. Finally, Paris-based CRID is also linked to ECOSOC, as well as to the European Commission and to UNCCD. The sociogram also reveals extensive interconnections between foundations and IGOs: $40 \%$ of all relations within the 3-core link foundations to IGOs. Overall, these patterns are consistent with the NGOization narrative: at 
the core of the network we find an intermingling of TAPGs, IGOs and foundations. However, not all foundations and IGOs are created equally; the Ford Foundation, often seen as a hegemonic and coopting institution (Parmar 2012), is a far cry from Isvara Foundation which identifies strongly with globalization-from-below and the critique of neoliberalism. ${ }^{7}$ And the Gates Foundation - the largest NGO funder and the clearest example (from the funding side) of NGOization - is nowhere to be found in the neighborhood of any TAPGs.

While the network analysis is consistent with the NGOization thesis, it does not offer any information on the content of relationships between TAPGs, IGOs and foundations. In the next section we present insights from interviews with TAPGs main protagonists, drawing a richer account of the struggles these groups face in their relations with hegemonic institutions and funders.

\section{Interviews}

The activist-intellectuals whose agency contributes to the alternative knowledge that TAPGs produce are an especially interesting population with which to explore how NGOization and financial dependence play out within a global political field. As organic intellectuals of a putative global left, working within groups that are mostly organized as NGOs, they may be particularly sensitized to these issues, and to practices that might mitigate the worst coopting effects. By probing these issues with a select sample of such activist-intellectuals, we can explore not only the challenges of NGOization and the limits that are imposed on TAPGs as agencies of counterhegemony, but also perhaps some limitations in the NGOization narrative itself.

Between May 2012 and June 2013 the first author conducted interviews, mostly in person, with 91 activist-intellectuals in transnational alternative policy groups. Ten of our 16 groups were studied in depth through site visits that lasted from one week to four weeks, during which interviews were conducted with 5-12 participants. Each of the other six groups participated in the study by means of a single interview, typically with the executive director. Interviews ranged quite widely across topics relevant to counter-hegemonic KPM; our analysis here focuses on what our informants had to say in response to three probes: 
- Some activists warn of the "NGOization" of movements; that is, their institutionalization and depoliticization as NGOs seek legitimacy and funds from the powerful. In your experience, is NGOization a problem in alter-globalization politics? If so, how does [TAPG]'s work relate to NGOization?

- What are [TAPG]'s main sources of funds? Names of key funding bodies? How does the issue of funding shape [TAPG]'s activities? Is core funding secure? Does funding tend to be project-based?

- Some say that in the so-called 'age of austerity' after the crisis of 2008 , it is now more difficult for progressive NGOs to obtain funding and thus to maintain the same level of activity. What is the situation with your group; how has [TAPG] adapted to austerity?

Participants in the interviews often gave lengthy narratives of NGOization, confirming it as a lived reality and adding detail on how it operates. At CCS, Executive Director Patrick Bond compared NGOs to 'ladling soup in the global soup kitchen,' whereas Samir Amin, founder of TWF, understands NGOs as 'part of the system of managing the system'. Rajesh Tandon, founder of PRIA stated that NGOization entails two problematic displacements (1) the NGOs' survival becomes the main end around which work is organized, displacing other goals; (2) NGOization displaces local voice.

In fact, TAPG protagonists generally displayed a critical awareness of NGOization as a problematic phenomenon and positioned themselves in opposition to it. PPSG founder Ichiyo Muto recalled that the practices of NGOization, both at the UN and around the Japanese state, formed 'a background against which we set [PPSG] up.' At RosaLux, Jorg Schultz took a strong stance against NGOization and stated that RosaLux is not looking to take over governmental duties and responsibilities but is committed to a robust public sector.

Our informants often saw NGOization and financial dependence as intimately linked. Victoria Tauli-Corpuz, an IFG board member, stated: 
I think the main problem is that a lot of donors would rather fund NGOs who have systems that are consistent with what donors want to have, so in that process, some of the NGOs really are capturing the resources and since they have all the resources, they are able to really influence how the movements also are proceeding.

Tauli-Corpuz also pointed to the effects of emergent donor preferences that force groups to regroup into coalitions whose secretariats then form bureaucracies detached from the actual constituencies of the coalition. She laid the blame for this fissure squarely on donors who 'want to simplify their lives.'

'One of the biggest casualties' of NGOization, according to TNI's Brid Brennan, has been a process of fragmentation and specialization that has diverted attention from 'the bigger picture' and has 'prevented a movement from emerging.' Brennan related this to the rise in the last two decades of 'a new kind of professional activist' and to 'the heavy demand of administrative work' required to satisfy funders. TWN's Yoke Ling Chee saw some initial benefit in the way the United Nations sustainable development process organized major groups, 'because it opened up not just NGOs but different constituents.' But this process 'quickly [put] them into silos,' with fragmenting consequences for activists interested in working across movement domains. Patrick Bond invoked 'silo' to describe NGOization, noting: 'that's where the funders are comfortable in not challenging the system.' For Bond, NGOization extends to several other problems:

the bureaucratization of struggle, the taming of activists, their petite bourgeoisification, the professionalization and inappropriate use of all manner of jargon and the sort of participation fetish, excessive emphasis on process, not a particularly good sense of when ends justify means and when means can be used to ramp up a fear of conflict.

IFG's Victor Menotti summed up the net effect of NGOization with an image of disempowerment through cooptation. 'Going down that NGO road disempowers you to deal with the systemic issues. You're constantly trying to figure out: how can I operate within the system and overthrow the system or replace the system, transform the system?' 
Perhaps the sharpest critique of NGOization was registered by TNI's Fiona Dove, who drew an interesting parallel between the concentration of wealth and power within neoliberal capitalism and the trajectory of global civil society:

NGOs are basically now either getting into bed with corporations or selling themselves as service-providers - and going for emergency aid money - because that's where the money is.... It's kind of like a parallel microcosm of what's going on in the world at large - this kind of concentration, at the top, of all the resources.

Dove's colleague Satoko Kishimoto also saw NGOization as a 'huge problem', rooted in a 'technocratic approach' that creates problems in the policy formation arena. 'But', she continued, 'this is one side of the question - one side of the reality we are in.'

This sampling of comments from our informants shows a deep, practically grounded understanding of the problems of NGOization and financial dependence. Although most of them are structured as NGOs, TAPGs are sites of critical, reflexive knowledge production. That does not mean that they escape problems of NGOization, but it may improve their prospects for mitigating them. One resource in such mitigation might arise from reframing the issue in a way that opens out to counter-strategies. In fact Kishimoto's point - that NGOization is 'one side of the question,' was echoed by many participants, whose analyses added nuance to the NGOization narrative as invoked in the critical academic literature. It is to these reflections that we now turn.

\section{Nuance in understanding $N G O s$}

Some participants queried certain stylizations and assumptions that seem built into the NGOization narrative, or at least the standard version of it summarized in our introduction. The narrative focuses perhaps inordinately upon form - the organizational form of the NGO, with an office, formal positions, a budget, etc. - while ignoring political content. Citing Focus on the Global South, Teivo Teivainen of NIGD noted that 'you can have organizations that [...] are clearly part of social movement articulations [although] in their form ... they are something close to an NGO, with an office, etc.' The point here is that something deeper may be at work than 
whether a group has resources that enable it to have an office, or even paid staff. Along similar lines, TNI's Jun Borras argued that the thesis of NGOization is misleading.

This framing actually has been used selectively by many comrades for very specific political agendas but it doesn't hold... it's a false dichotomy of NGO/movement: [that] NGO has no base, NGO corners all the money, has no legitimacy, it's undemocratic, rich and demobilizes movements.

The NGOization thesis, according to Borras, reduces profound political questions to organizational form, when in fact many social movements have broad resources and are run undemocratically, whereas 'countless NGOs are radical, have no money, [and] mobilize a radical base.'

Yoke Ling Chee, Executive Director of TWN, also wondered if more profound political issues were really well framed within an NGOization narrative, which tends to stylize movements as fluid and free of organizational constraint: "when you talk about movement, to the extent it has an impact, it has to be organized. And organization itself requires, whether you like it or not, some degree of hierarchy.' Thus, the question 'is not so much the NGOization of movements. It's how spaces should be created in policy-making at all levels that actually allow the maximum ... participation.' Yet 'the farther you go to the international level, the harder it is for people to get there,' for financial and logistical reasons. In this interpretation, the tendency for groups like TWN to play major roles at the international level is not necessarily symptomatic of their 'taking space away’ from grassroots movements. Such a voluntaristic interpretation assumes that movements could otherwise simply step into abstracted political spaces from which they have already been structurally excluded. The key issues are whether and how it may be possible for justice-oriented NGOs to work effectively within such spaces.

Other aspects of TAPG practice reported to us introduce further caveats. Pien Metaal pointed out that TNI's Drugs and Democracy program gets much of its funding from one of the world's top capitalists - George Soros and his Open Society Foundations. Yet, she claimed that the funds did not condition TNI practice; rather: 
funds from the powerful make it possible for us to do our work. And of course, you always have to be critical and look at what the effect of your work is and the fact that you accept it and you are part of this.

PRIA's Kaustuv Bandopadyay noted that PRIA's extensive offices in south New Delhi are indicative of NGOization, yet they provide grassroots groups with crucial meeting space.

[T] his has given us an opportunity to bring people [together] - we don't have to pay for anyone, and 20 people can just come and $[\ldots]$ have discussion for a day. So how many organizations can do that? That's the kind of advantage, I'd say....

Such facilities are integral to PRIA's project of participatory knowledge production. This does not discount the dilemmas involved in securing and maintaining them within a capitalist political economy.

PRIA's Nishu Kaul added further nuance to Bandopadyay's interpretation, and pointed to an additional strategic element that is underplayed in typical accounts of NGOization. The detachment of some NGOs from direct-action movement politics does not necessarily reflect the depoliticizing effects of bureaucratization, professionalization and financial dependency. It can also be a strategic response to the threat of state repression. In Nishu's estimation,

I think PRIA as an institution, has been playing it a little safe because we have not gone into very activist mode, where PRIA would be looked at critically. Because in our country, it is becoming an issue that the organizations who are raising issues ... are being looked at very critically; and many such organizations have even been blacklisted.

This narrative corresponds in obvious ways to that of NGOization, and one could chastise PRIA for 'playing it safe'; yet the issue of state repression (whether in India or elsewhere, whether against NGOs or grassroots movements) is a real one which perhaps gets underestimated if we rely too singularly on NGOization as a grand narrative.

In various ways, participants also raised more explicit questions about the adequacy of a simple NGO-vs-movements binary (a point made elegantly in one of the key texts on NGOization; Choudry and Kapoor 2013: 19). Susan George, whose leadership in TNI goes back to its origins, 
made a clear distinction between NGOs of the left and right, which informs TNI's collaboration strategies:

you can't trust the WWF and you can't trust Oxfam. And there's a certain number of people that you just know that they're going to cave at the first instance. I would say we just know that and we take that into account.

Michel Lambert of Alternatives International insisted on a distinction between 'service NGOs' that work on whatever issue happens to be popular with funders and 'citizen-based organizations where there is a real analysis, a real political perspective - from the left or mid-left.'

Similarly, for Karin Gabbert of RosaLux, collaboration with NGOs is a way to get access to certain people who 'are treasures of knowledge of movements and organizations of the past forty or fifty years.' The challenge, in sum, is to work with this organizational form in ways that circumvent the problems to which the NGOization narrative calls attention. This means choosing one's NGO partners carefully and even looking within NGOs to particular individuals, since neither NGOs nor movements are homogeneous entities.

This troubling of the NGO/movements binary leads toward a richer conception of the role NGOs play within what RosaLux activist-intellectuals call a mosaic left - composed of many movements and organizational forms. TAPG protagonists, positioned as they are at key articulation points between various movements, NGOs, alternative media and other groups on the left, offered some important insights on this matter. Hilary Wainwright of TNI acknowledged the problems flagged within the NGOization narrative, but she echoed Jun Borras in situating the issue less in terms of organizational form than in terms of political commitment:

I think it's important to think of NGOs as simply a residual category - if you're not a trade union, and you're not a political party, you must be an NGO. I wouldn't talk about NGOs per se as the problem. I'd more identify particular kinds of apolitical organizations whose goals increasingly get defined by their funding.

Wainwright's colleague Nick Buxton took this insight a step further, noting that NGOization has two sides. On the one hand, it can lead to a professionalization that undermines everything that cannot 'get turned into a log frame' or repurposed to match funders' needs; on the other hand, professionalizing an 
organization helps maximize the impact of limited resources, especially in terms of communications and publications.

Putting these reflections together, in appraising an NGO, the key issue is its ends - its political commitment and vision - which are not mechanically determined by a structural process of NGOization, and which may be well served by certain professionalizing practices.

Informants at the Rosa Luxemburg Foundation's Institute of Social Analysis (IfG) contributed insights on the strategic need to facilitate the mosaic left's development into a 'transformative left'. In IfG director Michael Brie's view, the problem is not only in NGOization. I think the problem is that the left, of course, is constituted by really different types of organizations with their own rights and merits but also there are a lot of limits. What I would say we are missing ... [is] 'militancy'. But militancy is a very demanding task - to be militant, real militant.

The image of a mosaic left, differentiated in terms of cultures, networks and organizational forms, is richer, and closer to reality, than the NGO/movements binary. Indeed, for RosaLux's Steffen Kuehn, dividing political actors into movements and NGOs is strange: "movement" is much broader: ... parties and unions and NGO-active people can of course be part of movements.' For Kuehn, NGOs can be 'bridges between the mainstream and the radical left,' with a broader base than the core of movements. But they can also be harmful to movements and 'canalize the anger and the creativity of many people and put them into something that is completely harmless.'

Katharina Puehl took a similar, long view of movements, institutionalization and NGOs. She emphasized their complementarity:

If you didn't have NGOs in Germany, the democratic landscape would be not as diverse as it is today, and these are, of course, still important actors in the field of democratizing civil society's discourses, interests. You have to have a platform to speak from. You have to have resources, be they material or immaterial to transform discourses. [...] I don't think that everything can be social movement all the time. 
RosaLux itself is an unusual organization which, as Alex Dimerovic insisted, is 'not an NGO; it's a state-funded and state-controlled..., it's part of the state apparatus. It's on the left and gives support to the left, but it's state funded, because it's close to a party.' On its face, such a scenario appears as one of state capture, from the start. And as Jorg Schultz confirmed, the RosaLux (itself a major funder of left organizations worldwide) is constrained, but still has a broad range of options.

The space left for us is wide... in many of the countries where we work, we support more or less opposition movements - people, organizations that are not in government. Sometimes the German government cooperates with the foreign government, while we support the opposition.... We would not, and we cannot, support an armed struggle, for example, so that's a constraint. There are always some issues from time to time which have to be negotiated, discussed with our funder. But in principle we are quite free to do what we want to do, provided we submit our proposals to them.

Apart from confirming the already well-established view that the state is an ensemble of many relations that offers a contradictory terrain of struggle even if the playing field is sharply sloped to the advantage of the ruling class (Jessop, 2007), reflections from protagonists at RosaLux seem consistent with Alex Dimerovic's assertion that 'what we now have is a kind of a postNGOization of social movements, because everybody now knows about this effect. So you have a well-differentiated NGO world.' Again, the NGOization thesis tends to homogenize a differentiated reality.

\section{Preventative measures}

Complementing these nuancing contributions to thinking about NGOization, our participants offered a range of insights on ways their groups have addressed challenges tagged by this term. Surveying their reflections, two themes stand out: (1) responding to the challenge of funding, i.e., of mobilizing financial resources, and (2) constructing relations with partners on the left that are ethico-political rather than instrumental, appropriative or 'gatekeeping' in character. 
One response to the funding challenge, well exemplified by Alternatives International, is to shift from reliance on donors to a membership base. When the hard-right Canadian federal government effectively de-funded Alternatives between 2008 and 2012, this became necessary. A related approach is to keep the organization as light-footed as possible, minimizing funding needs, while choosing one's funders carefully so as to avoid cooptation. The best exemplar here is DAWN, where, as Nicole Bidegain noted,

because we don't have a lot of funds, $[\ldots]$ we are able to set the agenda and people who fund us know that there is a very good quality job for coins, because we work for free most of [the time]. Much of the money goes to activities, not to salaries.

At TNI, Daniel Chávez described a strategy of selectivity regarding funders, to preempt possible cooptation: 'we would never accept any funding that puts some condition on the kind of issues we would work on, the kind of social actors or political actors we would interact with, so I don't see that as a problem.' He also reported on a safety-in-numbers approach, which strengthens TNI's position vis-à-vis its funders: 'when we get money from this kind of funders, usually we don't apply alone; we apply as part of a consortium with other organizations who share our perspective.' TNI's Martin Jelsma noted a complementary practice - reducing dependency by seeking multiple funders:

We're not $[\ldots]$ really dependent on one funder who could therefore have a lot of influence on what we're doing, and that has been [the] attempt, at least, from the start with TNI. [...] We always define our own agenda and programming and on that basis try to find the funder who is willing to fund it.

These practices enable TNI to maintain considerable autonomy while accessing necessary funds. Similarly, at PRIA according to Rajesh Tandon, 'we have always taken a strategy of not receiving more than $25 \%$ of our funds from a single agency in order to protect our intellectual autonomy' (cf. Figure 1, above). Tandon's colleague Martha Farrell acknowledged that PRIA went through a phase of 'projectization', in which some projects were taken up in order to generate revenue, but upon critical reflection the group shifted course and opted to 'use PRIA's core funding to support what we believe needs to be done.' PRIA's Sumona Dasgupta offered an 
insightful reflection on the need for principled, ethico-political thinking in negotiating what is, in actuality, a difficult but not inherently debilitating challenge for NGOs in a neoliberal world.

There is nothing free about the market [...]. It's a lived reality in all our lives. We have no choice perhaps but to negotiate with it. How do you negotiate with it in a principled way, without giving up your values and norms is really the challenge that PRIA is facing - and faces every moment when it comes to funders, ... when it comes to the kind of work that we will pick up to do, and the choice of our research topics....

At Focus, Andrew de Sousa's reflection on the same topic showed a similar self-critical understanding of dependence on external funders:

...we're an 'NGO' because we get almost nothing from individual donations. [W]e're a think tank and we're not a mass movement. I think that's part of it to be making sure that we're clear that that is what we are, so when we engage with others, how do we make sure that we don't behave in the way that maybe Oxfam would or even ActionAid [...]. What they do $[\ldots]$ can sometimes silence movements or really distort what movements are saying.

De Sousa's self-critical reflection directs us to the second strategy for mitigating NGOization the insistence on building ethico-political relations with movement partners. According to his colleague at Focus, Afsar Jafri, Focus has thus far managed to avoid NGOization and has retained its movement allies by giving them credit for their work and not misappropriating voice, and by standing with them in the street, at the risk of displeasing some funders. The cost of resisting NGOization in this sense is limited financial resources, but the advantage is crucial to counter-hegemonic politics. It is precisely through building strong relationships with movements and subaltern publics that an alternative historical bloc can be formed. TAPGs can play an important facilitative role in that process. The key is to be mindful of the actual role alternative policy groups can play in that broader process. For Satoko Kishimoto of TNI this involves close, supportive relations with movements and active engagement in their struggles: being 'part of the social movement, rather than part of the big NGO actors, which is in her view 'the only way... not to be put in the situation of NGOization.' 
Executive Director Fiona Dove explained that TNI does not directly fund groups but works out joint programs it helps coordinate, making 'sure that it's very clear to everyone that we see this is as a common political project, and we're not a funding agency and we're not an NGO.' It is through such circumspect practices that TNI can avail itself of the trappings of an NGO - offices, paid, professional staff, funds, relations with state/intergovernmental bodies - yet avoid functioning as an NGO in the sense of NGOization.

The same attitude of mindful, democratic partnership and solidarity needs to inform engagements with statist bodies. At Focus, Jacques Chai Chomtongdi recounted an episode that highlighted both the danger of cooptation and the reality of democratic partnership.

Three weeks ago, we were negotiating with the World Bank. The movement people were there, and we wanted to challenge the REDD program in Thailand. The World Bank said 'no problem'. But seeing as I was the one lobbying and talking, they said 'okay, we invite you to the World Bank office tomorrow, we'll work together and do whatever you want'. I thought, 'If I go, maybe I can get the result I want or something similar, but even to do that, I will not have enough time to consult with the movement - are they willing for me, even though I am not representing them as such, to engage in the process?' So the only thing I can say is 'no' and I walk from the room, and the movement saw me doing that, and we all walked out of the process.

It is through such principled, solidaristic action that the trust essential to a counter-hegemonic bloc can be fostered. Indeed, Focus provides a particularly good example of an NGO in and of the grassroots. This involves two elements: refusing to appropriate voice, but also finding one's own independent voice that contributes to the conversation. For TAPGs, whose task is to develop analyses, strategies and visions that can be of value to various actors on the global left, both elements are imperative. Together they can contribute to a healthy relationship with movements. Focus's Joseph Purugganan primarily spoke to the first element and of the need to expand the space for movement views and participation:

What we've avoided is ... speaking for or on behalf of movements. So what we've tried to do is facilitate - if there are spaces at regional or global levels for articulation of views and 
analysis, as much as possible we try to give that space to movements, grassroots organizations.... For us, it's a conscious effort really to expand the space for broader participation of movements to allow for different points of view.

Focus's executive director, Pablo Solon, concurred, but went on to emphasize the second element:

...we don't want to try to speak for social movements and we respect the process of social movements. But that doesn't mean that we don't say what we think... Sometimes we know that some social movements will not agree with us, but we are not going to try to replace them at all or try to find a way to have our positions being adopted through an antidemocratic way or to use the issue of funding to prove our ideas, our proposals. So that creates a very healthy relation.

\section{Conclusions}

Findings from our two-pronged investigation may seem contradictory. The network analysis gives evidence consistent with the NGOization narrative. TAPGs link extensively to many INGOs, but also maintain relations with IGOs and foundations (themselves interlinked) which form part of the institutional structure of global governance and financial allocation. At the core of the network we find extensive intermingling of TAPGs, IGOs and foundations. Thus, TAPGs are not only embedded within an incipient global left (as per Carroll and Sapinski, 2013); they are also extensively connected to dominant institutions. They form part of a transnational infrastructure of dissent (Sears 2014), but also participate in a transnational infrastructure of consent. Yet the substantive meaning of these relations cannot be directly 'read off' of the network structure, which provides only a skeletal representation of the complicated relationships among its members.

TAPGs are particularly interesting organizations for exploring intricacies of these relationships, and for problematizing the notion of NGOization as a grand narrative. In part this is because the political projects TAPGs set themselves (producing and mobilizing counter-hegemonic knowledge) make them quite unlike the stereotypical service-oriented NGO. By implication, 
TAPG protagonists consciously and critically think about NGOization. They struggle with its debilitating impact but as we have seen, they also find ways around it. In the process, they deconstruct NGOization as an obdurate political reality. The effect is to call into question the narrative of NGOization itself, as an overarching account of the trajectory of groups that adopt formal-organizational features and that rely on external funding.

Our participants provided nuanced accounts that begin to specify the contingencies mediating between, on the one hand, the resort to formal organization, to engagement with IGOs and to external funding, and on the other hand the descent into hegemonic incorporation. Creative responses to funding challenges and the ongoing construction of ethico-political relations with movement partners comprise two such contingencies. Each highlights the agentic role movement organizations may play in avoiding their own cooptation. Recent strategic thinking in transnational civil society groups such as AWID and CIVICUS shows the same reflexive, selfcritical perspective as evidenced in our interviews. ${ }^{8}$ Further research is required to explore this key issue more fully.

This is not to gainsay the accuracy of NGOization as a descriptor for processes of hegemonic incorporation, particularly among NGOs that embrace 'apolitical', service-oriented mandates. The point is that such processes are not automatic, and, for critically reflexive groups such as TAPGs, capture only 'one side' of the reality in which they are active protagonists. On the left, the contradictions between volunteerism without infrastructure and professionalization with problematic funding are widespread. Every bridge the left builds towards the mainstream has contradictory characteristics, threatening to assimilate the radical into the dominant while also creating new openings for counter-hegemony. ${ }^{9}$ In a neoliberal political-economic environment, the future of counter-hegemonic politics hinges partly on our identifying how 'preventative measures' can be brought to bear on processes of NGOization.

\section{Funding acknowledgement}

This research was funded by a grant from the Social Sciences and Humanities Research Council of Canada. 


\section{Notes}

1 Our analysis differs from Carroll and Sapinski's (2013) in that they excluded foundations and IGOs/state bodies from consideration.

2 Organizations were coded mainly using the YIO's classification. We classified a small number of ambiguous cases on the basis of organizations' names and information provided on their websites. For TAPGs not listed in the YIO, organizations' websites were used; in two cases where no information was found on websites, data on organizational affiliations were obtained via email from the TAPGs themselves. This extensive relational database was further expanded using data from interviews the first author conducted with each TAPG's staff between May 2012 and June 2013.

3 Another reason for not distinguishing between link types is the lack of specificity in $Y I O$ classifications of certain relations. In particular, funding flows are often described as 'partnerships'. It is impossible to determine the actual content of such relations from the information available.

4 See Table 1 for the full names of TAPGs.

$5 \mathrm{~A} \mathrm{k}$-core is a connected network, all of whose members are linked to at least k fellow members (Seidman, 1983). Thus, every organization in the 3-core is directly tied to at least three other 3core members.

6 See Table 4 for the full names of IGOs and foundations.

7 See www.isvarafoundation.org/index.htm, accessed 23 August 2014.

8 For an analysis of strategic thinking in AWID (the Association for Women's Rights in Development) see Harcourt (2013). The November, 2014 open letter issued by CIVICUS and endorsed by many INGOs is particularly exemplary (Sriskandarajah et al. 2014).

9 We thank an anonymous reviewer for this elegant phrasing. 


\section{References}

Alvarez SE (1999) Advocating feminism: The Latin American feminist NGO ‘boom’. International Feminist Journal of Politics 1(2): 181-209.

Bob C (2005) The marketing of rebellion: insurgents, media and international activism. New York: Cambridge University Press.

Brem-Wilson, J (2015) Towards food sovereignty: Interrogating peasant voice in the United Nations Committee on World Food Security." Journal of Peasant Studies 42(1):73-95.

Carroll WK (2013) Networks of cognitive praxis: transnational class formation from below? Globalizations 10(5): 651-670.

Carroll WK (2014) Alternative policy groups and transnational counter-hegemonic struggle. In: Atasoy Y (ed) Global Economic Crisis and the Politics of Diversity. London and New York: Palgrave Macmillan, pp. 259-284.

Carroll WK and Sapinski JP (2013) Embedding post-capitalist alternatives? The global network of alternative knowledge production and mobilization. Journal of World-Systems Research 19(2): 211-240.

Choudry A (2010) Global justice? Contesting NGOization: knowledge politics and containment in antiglobalization networks. In: Choudry A and Kapoor D (eds) Learning from the ground up: global perspectives on social movements and knowledge production. New York:

Palgrave Macmillan, pp. 17-34.

Choudry A and Kapoor D (2010) Learning from the ground up: global perspectives on social movements and knowledge production. In: Choudry A and Kapoor D (eds) Learning from the ground up: global perspectives on social movements and knowledge production. New York: Palgrave Macmillan, pp. 1-13.

Choudry A and Kapoor D (eds) (2013) NGOization: complicity, contradictions and prospects. London: Zed Books.

Dauvergne P and LeBaron G (2014) Protest Inc.: The corporatization of activism. Hoboken, NJ: John Wiley \& Sons.

Dupuis-Déri F (2013) Broyer du noir : La répression policière de la 'déviance politique' au Québec. In: Dupuis-Déri F (ed.) À qui la rue? Répression policière et mouvements sociaux. Montréal: Écosociété, pp. 122-158.

Feldman B (2007) Report from the field: left media and left think tanks - foundation-managed protest? Critical Sociology 33(3): 427-446. 
Ferguson J (2006) Global shadows: Africa in the neoliberal world order. Durham, NC: Duke University Press.

Goldman M (2005) Imperial nature: The World Bank and struggles for social justice in the age of globalization. New Haven, CT: Yale University Press.

Guilhot N (2007) Reforming the world: George Soros, global capitalism and the philanthropic management of the social sciences. Critical Sociology 33(3): 447-477.

Hervé A (2014) Roles of brokerage networks in transnational advocacy networks. Environmental Politics 23(3): 395-416.

INCITE! Women of Color Against Violence (2007) The revolution will not be funded: Beyond the non-profit industrial complex. Cambridge, MA: South End Press.

Jessop B (2007) State power. Cambridge and Malden, MA: Polity Press.

Keck ME and Sikkink K (1998) Activists beyond borders: Advocacy networks in international politics. Ithaca, NY: Cornell University Press.

Lang, S (2013) NGOs, civil society, and the public sphere. New York: Cambridge University Press.

McKeon N (2009) The United Nations and civil society: legitimating global governance - whose voice? London: Zed Books.

Parmar I (2012) Foundation networks and American hegemony. European Journal of American studies 7(1). Available at: http://ejas.revues.org/9476.

Petras J (1997) Imperialism and NGOs in Latin America. Monthly Review 49(7). Available at: https://monthlyreview.org/1997/12/01/imperialism-and-ngos-in-latin-america/.

Research Unit for Political Economy (2007) Foundations and mass movements: The case of the World Social Forum. Critical Sociology 33(3): 505-536.

Santos B de S (2006) The rise of the global left: The World Social Forum and beyond. London: Zed Books.

Scholl C and Freyberg-Inan A (2013) Hegemony's dirty tricks: Explaining counterglobalization's weakness in times of neoliberal crisis. Globalizations 10(4): 619-634.

Sear, A (2014) The next new left: A history of the future. Halifax, NS: Fernwood Publishing. Seidman SB (1983) Network structure and minimum degree. Social Networks 5(3): 269-287.

Shivji IG (2007) Silences in NGO discourse: the role and future of NGOs in Africa. Nairobi and Oxford: Fahamu - Networks for Social Justice. 
Smith J (2012) Transnational activism and global social change. In: Moksnes H and Melin M (eds) Global civil society: shifting powers in a shifting world. Uppsala: Uppsala Centre for Sustainable Development, Uppsala Universitet, pp. 9-24.

Smith J and Wiest D (2012) Social movements in the world-system: The politics of crisis and transformation. New York: Russell Sage Foundation.

Sriskandarajah D, Houghton I, Naidoo J, Hodgson J, Tørres L, Heywood M, O’Brien-Onyeka M, Mthati S (2014) An open letter to our fellow activists across the globe: Building from below and beyond borders. Civicus Blog [blog]. 6 August. Available (consulted April 30 2015) at: http://blogs.civicus.org/civicus/2014/08/06/an-open-letter-to-our-fellow-activists-acrossthe-globe-building-from-below-and-beyond-borders/

UIA (2012) Yearbook of international organizations. Brussels: Brill. Available at: http://ybio.brillonline.nl. 


\section{Tables and figures}

Table 1. Sixteen Transnational Alternative Policy Groups

\begin{tabular}{|c|c|c|}
\hline Est'd & Name & Abbreviation \\
\hline 1974 & Transnational Institute (Amsterdam) & TNI \\
\hline 1975 & Third World Forum (Dakar) & TWF \\
\hline 1976 & Tricontinental Centre (Louvain-la-Neuve, Belgium) & CETRI \\
\hline 1976 & Centre de recherche et d'information pour le développement (Paris) & CRID \\
\hline 1982 & Society for Participatory Research in Asia (New Delhi) & PRIA \\
\hline 1984 & Third World Network (Penang) & TWN \\
\hline 1984 & Development Alternatives with Women for a New Era (Manila) & DAWN \\
\hline 1989 & Third World Institute/Social Watch (Montevideo) & ITeM \\
\hline 1990 & Rosa Luxemburg Foundation (Berlin) & RosaLux \\
\hline 1994 & International Forum on Globalization (San Francisco) & IFG \\
\hline 1995 & Focus on the Global South (Bangkok) & Focus \\
\hline 1997 & Network Institute for Global Democratization (Helsinki) & NIGD \\
\hline 1998 & People's Plan Study Group (Tokyo) & PPSG \\
\hline 2001 & Centre for Civil Society (Durban) & $\mathrm{CCS}$ \\
\hline 2005 & Alternatives International (Montréal) & Alter-Inter \\
\hline 2005 & India Institute for Critical Action: Centre in Movement (New Delhi) & CACIM \\
\hline
\end{tabular}


Table 2. Mean intra- and inter-sectoral distances among four types of organization

\begin{tabular}{lcccc}
\hline & TAPG & Foundation & IGO/State & NGO \\
\hline TAPG & 2.092 & 2.578 & 2.613 & 2.528 \\
Foundation & 2.578 & 2.955 & 3.048 & 3.035 \\
IGO/State & 2.613 & 3.048 & 3.041 & 3.078 \\
NGO & 2.528 & 3.035 & 3.078 & 3.025 \\
\hline
\end{tabular}


Table 3. Size and Composition of TAPGs' immediate neighborhoods

\begin{tabular}{|c|c|c|c|c|c|c|}
\hline \multirow[b]{2}{*}{ TAPG $^{\mathbf{a}}$} & \multirow[b]{2}{*}{ Size } & \multicolumn{5}{|c|}{ Proportion of neighborhood comprised of... } \\
\hline & & $\begin{array}{c}\text { Other } \\
\text { TAPGs }\end{array}$ & $\begin{array}{l}\text { Founda- } \\
\text { tions }\end{array}$ & IGOs/ State & NGOs & Total \\
\hline PRIA & 23 & 0.043 & 0.217 & 0.261 & 0.478 & 1.000 \\
\hline TNI & 35 & 0.086 & 0.086 & 0.286 & 0.543 & 1.000 \\
\hline DAWN & 34 & 0.059 & 0.059 & 0.235 & 0.647 & 1.000 \\
\hline CETRI & 7 & 0.000 & 0.000 & 0.286 & 0.714 & 1.000 \\
\hline ITeM & 28 & 0.036 & 0.107 & 0.179 & 0.679 & 1.000 \\
\hline CRID & 47 & 0.000 & 0.149 & 0.085 & 0.766 & 1.000 \\
\hline $\mathrm{CCS}$ & 50 & 0.080 & 0.120 & 0.080 & 0.720 & 1.000 \\
\hline RosaLux & 44 & 0.068 & 0.068 & 0.114 & 0.750 & 1.000 \\
\hline TWN & 27 & 0.074 & 0.037 & 0.111 & 0.778 & 1.000 \\
\hline Focus & 50 & 0.140 & 0.060 & 0.080 & 0.720 & 1.000 \\
\hline Alter-Inter & 11 & 0.000 & 0.000 & 0.091 & 0.909 & 1.000 \\
\hline PPSG & 17 & 0.059 & 0.059 & 0.000 & 0.882 & 1.000 \\
\hline CACIM & 20 & 0.050 & 0.000 & 0.050 & 0.900 & 1.000 \\
\hline TWF & 24 & 0.083 & 0.000 & 0.042 & 0.875 & 1.000 \\
\hline IFG & 8 & 0.000 & 0.000 & 0.000 & 1.000 & 1.000 \\
\hline NIGD & 5 & 0.200 & 0.000 & 0.000 & 0.800 & 1.000 \\
\hline $\begin{array}{l}\text { Mean } \\
\text { (st. dev.) }\end{array}$ & $\begin{array}{c}26.9 \\
(15.4)\end{array}$ & $\begin{array}{c}0.061 \\
(0.054)\end{array}$ & $\begin{array}{c}0.060 \\
(0.064)\end{array}$ & $\begin{array}{c}0.119 \\
(0.100)\end{array}$ & $\begin{array}{c}0.760 \\
(0.137)\end{array}$ & 1.000 \\
\hline
\end{tabular}

${ }^{\text {a }}$ Ranked according to the total proportion of foundations and IGOs/State agencies in each TAPG's neighborhood. 
Table 4. Abbreviations used in Figure 1

\begin{tabular}{|c|c|c|c|}
\hline Abbr..$^{a}$ & Full name & Abbr. & Full name \\
\hline \multicolumn{4}{|c|}{$\underline{\text { IGOs/State Bodies }}$} \\
\hline $\mathrm{EC}$ & European Community & UK-DFID & $\begin{array}{l}\text { UK Department for International } \\
\text { Development }\end{array}$ \\
\hline $\mathrm{EC} 1$ & European Commission & UNCCD & $\begin{array}{l}\text { UN Convention to Combat } \\
\text { Desertification (secretariat) }\end{array}$ \\
\hline ECOSOC & UN Economic and Social Council & UNCTAD & $\begin{array}{l}\text { UN Conference on Trade and } \\
\text { Development }\end{array}$ \\
\hline WB & World Bank & UNDP & UN Development Programme \\
\hline IDRC & $\begin{array}{l}\text { International Development Research } \\
\text { Centre }\end{array}$ & UNFCCC & $\begin{array}{l}\text { UN Framework Convention on Climate } \\
\text { Change (secretariat) }\end{array}$ \\
\hline SDC & Swiss Development Corporation & UNICEF & United Nations Children's Fund \\
\hline SIDA & $\begin{array}{l}\text { Swedish International Development } \\
\text { Agency }\end{array}$ & UN-Women & UN Women \\
\hline \multicolumn{4}{|c|}{$\underline{\text { Foundations }}$} \\
\hline AA & ActionAid & HWMT & Harold Wolpe Memorial Trust \\
\hline $\mathrm{AKF}$ & Aga Khan Foundation & MacArthur & MacArthur Foundation \\
\hline $\mathrm{CA}$ & Christian Aid & OWIF & One World International Foundation \\
\hline CSMF & Charles Stewart Mott Foundation & TDH & Fondation Terre des hommes \\
\hline DHF & Dag Hammasrkjöld Foundation & WOW & War on Want \\
\hline Ford & Ford Foundation & & \\
\hline
\end{tabular}

a Abbreviations for TAPGs are shown in Table 1. 


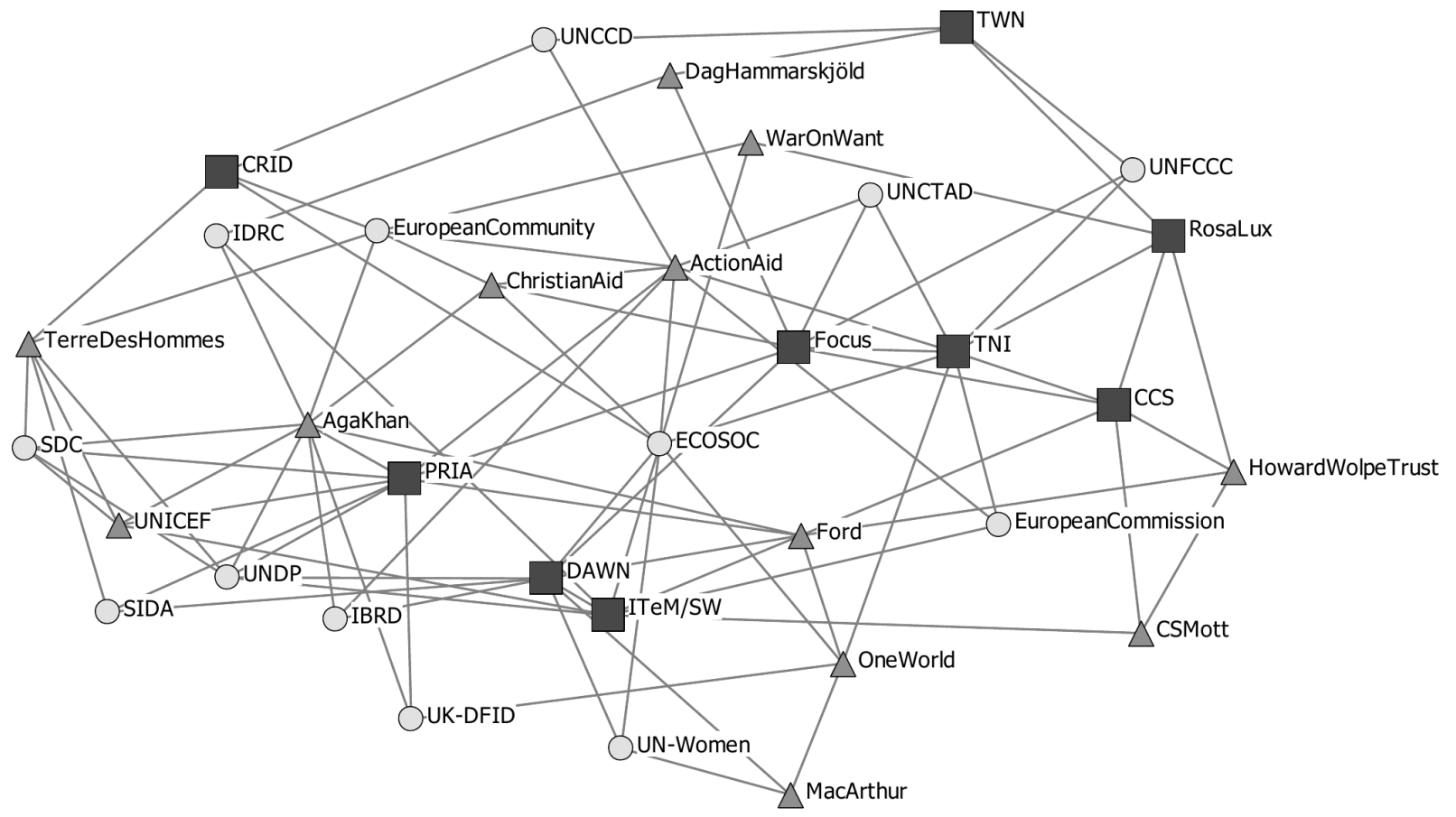

Key

Black squares: TAPGs Dark grey triangles: Foundations Light grey circles: IGOs

Figure 1. Relations between TAPGs, IGOs and foundations in the 3-core of the network 